УДК 669.24:621.452.3.03-226

М. В. ГРЕКОВА ${ }^{1}$, Н. Є. КАЛІНІНА ${ }^{2}$, В. Т. КАЛІНІН ${ }^{3}$, М. В. ГУЧЕНКОВ ${ }^{1}$, Є. О. ДЖУР ${ }^{2}$, О. С. ДУДНІКОВ ${ }^{4}$

${ }^{1}$ ДП «КБ «Південне», Дніпро

${ }^{2}$ Національний дніпровський університет ім. О. Гончара «ДНУ», Дніпро

${ }^{3}$ Національна металургійна академія Украӥни «НМетАУ», Дніпро

${ }^{4}$ Запорізький національний технічний університет «ЗНТУ», Запоріжжяя

\title{
ПІДВИЩЕННЯ СТРУКТУРНОЇ СТАБІЛЬНОСТІ ТА ВЛАСТИВОСТЕЙ ЖАРОМЦНИХ НІКЕЛЕВИХ СПЛАВІВ ДЛЯ ЛОПАТОК ГТД ОБРОБКОЮ НАНОМАТЕРІАЛАМИ
}

\begin{abstract}
Проведено аналітичний огляд існуючих представлень з проблеми підвищення жароміщності, жаростійкості і довговічності жаромічних нікелевих сплавів групи ЖС лопаток газотурбінних двигунів проведено аналіз впливу легуючих елементів сплавів на структурні перетворення, види зміцнення $і$ корозійну стійкість. Для обробки нікелевих розплавів запропоновано комплексний порошковий модифікатор на основі карбонітрида титану Ті (CN) з розміром частинок $50 . .100$ нм. Визначено параметри наномодифікатора. Досліджена макро- $і$ мікроструктура нікелевих сплавів ЖСЗ, ЖСЗДК. В модифікованих зразках досягнуто подрібнення зерна в 3 ... 5 разів і стабілізація структури в порівнянні з вихідним станом. Досягнуто також підвищення механічних властивостей сплавів: $\sigma_{B}-$ на $10 \%$; $\sigma_{0,2}-н а$ $13 \%$; $\delta$ - на $20 \%$ и КCU на $40 \%$. Випробування на високотемпературну корозію показали зментення глибини корозії модифікованих зразків на $25 \%$, шэо підтверджують ефект модифікування сплавів нанодисперсними модифікаторами.
\end{abstract}

Ключові слова: жароміцні нікелеві сплави, наномодифікатор, структура, властивості, лопатки газотурбінних двигунів.

\section{Вступ}

Забезпечення експлуатаційної надійності та довговічності авіаційно-космічних виробів - актуальна проблема сучасного виробництва як в авіаційній, так і в космічній галузях. Поліпшити якість та експлуатаційні властивості виробів можна, розробляючи нові та удосконалюючи існуючі матеріали. Ливарні жароміцні нікелеві сплави застосовують для виготовлення деталей авіаційних газотурбінних та ракетних двигунів. До деталей газотурбінних двигунів висувають такі вимоги: висока щільність і герметичність, відсутність пористості, стабільність розмірів, високий комплекс фізико-механічних характеристик, жароміцність, жаротривкість та довговічність [12]. Під час розробки жароміцних нікелевих сплавів зі заданими властивостями важливий етап обробки розплавів, оскільки технологія виготовлення впливає на кінцеву структуру виливків. На стадії обробки розплавів найефективніші операції модифікування. Сьогодні для модифікування нікелевих сплавів застосовують чисті метали: цирконій, титан, ітрій, а також тугоплавкі композиції, в тому числі нанорозмірного діапазону, на основі карбідів, нітридів, боридів і карбонітридів [1-3].

\section{Теоретична частина}

Під час розвитку виробництва жароміцних сплавів їх хімічний склад ставав все складнішим. Цей розвиток стимулювала потреба збільшити коефіцієнт корисної дії авіаційних газових турбін безперервним збільшенням робочих температур металу. Тому стали суворіші вимоги до міцності та жароміцності застосовуваних у турбіні матеріалів, суттєво ускладнилася конструкція лопаток турбін, виконання якої виявилося можливим тільки за допомогою жароміцних ливарних нікелевих сплавів. Високолеговані жароміцні сплави відносять до групи ЖС: ЖС6К, ЖС6У, ЖС32, ЖС6ФНК, ЖС6ФМ, ЖС6К-ВІ, ЖСЗДК.

До сьогодні підвищення надійності роботи турбін і збільшення експлуатаційного ресурсу деталей здійснюють за двома основними напрямками. Перший - заміна існуючих промислових жароміцних сплавів на нові. Другий - підвищення комплексу службових характеристик шляхом легування, модифікування існуючих промислових сплавів. Міжнародна практика виявила, що другий напрямок економічно вигідніший і перспективніший. Одним із основних принципів теорії легування жароміцних 
сплавів є принцип багатокомпонентного легування $[1,7,8]$, що призводить як до ускладнення складу і подрібнення часток зміцнювальних фаз, що виділяються з пересиченого твердого розчину під час старіння, так і до уповільнення їх коагуляції за підвищених температур внаслідок гальмування дифузійних процесів у матричному складнолегованому твердому розчині.

Таблиця 1

Легувальні елементи в жароміцних нікелевих сплавах

\begin{tabular}{|c|c|c|}
\hline Група & Елементи & Вплив \\
\hline \begin{tabular}{|l|} 
Елементи, що \\
входять до \\
складу матриці \\
сплаву
\end{tabular} & $\begin{array}{c}\text { Co, Cr, Mo, } \\
\text { W, V, Ti, } \\
\text { Al }\end{array}$ & $\begin{array}{l}\text { Твердорозчинне зміц- } \\
\text { нення. } \\
\text { Підвищення корозій- } \\
\text { ної тривкості }\end{array}$ \\
\hline $\begin{array}{l}\text { Елементи, що } \\
\text { входять до } \\
\text { складу } \gamma^{\prime} \text {-фази }\end{array}$ & $\begin{array}{c}\mathrm{Al}, \mathrm{Ti}, \mathrm{Nb} \\
\mathrm{Ta}\end{array}$ & Дисперсійне зміцнення \\
\hline $\begin{array}{l}\text { Карбідотвірні } \\
\text { елементи }\end{array}$ & $\begin{array}{c}\mathrm{Cr}, \mathrm{Mo}, \mathrm{W}, \\
\mathrm{V}, \mathrm{Nb}, \mathrm{Ta}, \\
\text { Ti, Hf }\end{array}$ & $\begin{array}{l}\text { Послаблення проков- } \\
\text { зування межами зерен }\end{array}$ \\
\hline $\begin{array}{l}\text { Поверхнево- } \\
\text { активні елемен- } \\
\text { ти }\end{array}$ & $\mathrm{Zr}, \mathrm{B}$ & $\begin{array}{l}\text { Збільшення в'язкості } \\
\text { руйнування } \\
\text { повзучості }\end{array}$ \\
\hline
\end{tabular}

Легувальні елементи в нікелевих сплавах залежно від їх внеску в зміцнення і корозійну тривкість, згідно з працею [46], можна розділити на кілька груп (табл. 7.19). Елементи, що входять до складу матриці. Принципово важливими особливостями нікелевих сплавів $є$ висока розчинність легувальних елементів у нікелевій матриці і збереження ГЦК-гратки до $\mathrm{T}=0,8 \mathrm{~T}_{\text {пл }}$ тривалий (до $10^{5}$ год) час. До елементів, що впливають на твердорозчинне зміцнення матричної $\gamma^{\prime}$-фази, відносять $\mathrm{Al}, \mathrm{Ti}, \mathrm{V}, \mathrm{W}, \mathrm{Mo}, \mathrm{Cr}$ i Со. Алюміній відіграє помітну роль у зміцненні твердого розчину і в утворенні зміцнювальних фаз. Хром не є ефективним зміцнювачем твердого розчину. Основна мета його впровадження - підвищити корозійну тривкість сплавів.

Алюміній i титан, що входять до складу $\gamma^{\prime}$-фази, здатні помітно зміцнювати твердий розчин, проте їх основне призначення в тому, щоб, взаємодіючі з нікелем, утворювати виділення $\gamma^{\prime}$-фази, забезпечуючи дисперсійне зміцнення жароміцних сплавів.

Експлуатаційна довговічність литих робочих лопаток суттєво залежить від стабільності структури і фізико-механічних властивостей жароміцних нікелевих сплавів. Оскільки можливість поліпшити властивості сплаву легуванням обмежена, можна його модифікувати. Теоретичні основи модифікування закладені у фундаментальних працях В. І. Данилова, П. Д. Данкова, В. Є. Неймарка, . А. Ребіндера, М. В. Мальцева, А. І. Гусєва.

\section{Експериментальна частина}

В основі модифікування первинного зерна нікелю - зародковий механізм. У модифікованому нікелевому сплаві є додаткові центри кристалізації, якими служать частинки металевих 3'єднань, спеціально введені в розплав. Кристалізація з багатьох центрів, штучно створених у розплаві, сприяє формуванню дрібнозернистої рівномірної структури металу. Однак не кожна чужорідна частинка, створена в розплаві, може бути центром кристалізації під час тверднення нікелевого сплаву. Зародком може служити частка, що має деякий критичний розмір і подібна структурно до речовини, що кристалізується на ній. Зокрема, між кристалічними решітками титану i нікелю $є$ необхідна структурна i розмірна відповідність, тому титан і з'єднання на його основі - ефективні модифікатори [3-6].

Аналіз результатів перспективних напрямків підвищення міцності металевих сплавів дає можливість зробити висновок про тенденції відхилення від традиційних методів твердорозчинного зміцнення. Роль нанодисперсних додатків-модифікаторів, наприклад, карбонітриду титану розміром $50 . .100$ нм, зводиться до створення в розплаві додаткових штучних центрів кристалізації $[7,8]$. Для цього такі додатки повинні бути сумірні з критичними зародками матричної фази і забезпечувати достатню їх кількість, щоб отримати в литві дрібнодисперсну структуру. Іншим чинником під час наномодифікування $\epsilon$ досягнення кристалографічної відповідності часток 3 модифікованою фазою, що кристалізується.

Проблема підвищення жароміцності нікелевих сплавів досить гостра і актуальна. Це викликано тим, що деталі ракетних і авіаційних газотурбінних двигунів під час експлуатації схильні до дії агресивного середовища палива за підвищених температур. Модифікування конструкційних сплавів - перспективний напрямок, що активно розвивається. Розрізняють поверхневе, об'ємне, комбіноване модифікування. Велика кількість металів та їх сполука у різному розмірному діапазоні, в тому числі і нанодисперсні, можуть бути ефективними модифікаторами.

Нікелеві сплави типу ЖС: ЖС3, ЖС6У, ЖС6К, ЖС26, ЖС32 використовують для виготовлення деталей двигунів, які випускають сьогодні на провідних підприємствах України. Марку сплаву вибирають залежно від робочої температури вузла. Хімічний склад сплавів наведено в табл. 2.

Як основу для модифікувального комплексу розглядають металоподібні тугоплавкі сполуки титану 
з вуглецем і азотом: карбіди, нітриди і карбонітріди. Карбонітрид титану, карбіди і нітриди титану мають кубічну гратку, високі температурну тривкість і температуру плавлення. Для всіх вивчених складів нанопорошків залежності аналогічні: зі зменшенням радіуса частинок до 100 нм їхня питома поверхня різко збільшується, досягаючи $12 \mathrm{~m}^{2} /$ г для карбонітриду титану (табл. 3).

Таблиця 2 Хімічний склад промислових ливарних жароміцних нікелевих сплавів

\begin{tabular}{|c|c|c|c|c|c|c|c|c|c|}
\hline \multirow{2}{*}{$\begin{array}{l}\text { Марка } \\
\text { сплаву }\end{array}$} & \multicolumn{9}{|c|}{ Вміст елементів, мас. \% } \\
\hline & $\mathrm{Al}$ & $\mathrm{Ti}$ & $\mathrm{Cr}$ & Mo & W & Co & $\mathrm{C}$ & $\begin{array}{c}\mathrm{Mn}, \\
\mathrm{Si}\end{array}$ & $\mathrm{Ni}$ \\
\hline \multirow{3}{*}{ ЖС3 } & 1,1 & 1,3 & 14,0 & 3,0 & 4,0 & - & 0,10 & \multirow{3}{*}{$\leq 0,4$} & \multirow{3}{*}{$\mathrm{OcH}$} \\
\hline & & $\ldots$ & $\cdots$ & $\ldots$ & $\ldots$ & & $\ldots$ & & \\
\hline & 2,5 & 2,1 & 17,5 & 4,2 & 6,7 & & 0,18 & & \\
\hline \multirow{3}{*}{ ЖС6К } & 5,4 & 2,5 & 10,0 & 3,7 & 4,8 & 4,2 & 0,13 & \multirow{3}{*}{$\leq 0,2$} & \multirow{3}{*}{$\mathrm{OcH}$} \\
\hline & & $\ldots$ & ... & $\ldots$ & ... & . & 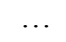 & & \\
\hline & 6,0 & 3,0 & 11,0 & 4,2 & 5,3 & 4,9 & 0,19 & & \\
\hline \multirow{3}{*}{ ЖС6У } & 5,2 & 2,2 & 8,6 & 1,2 & 9,8 & 9,4 & 0,13 & \multirow{3}{*}{$\leq 0,2$} & \multirow{3}{*}{$\mathrm{OcH}$} \\
\hline & .. & $\ldots$ & & $\ldots$ & $\ldots$ & $\ldots$ & & & \\
\hline & 5,8 & 2,8 & 9,3 & 1,6 & 10,5 & 10,4 & 0,19 & & \\
\hline \multirow{3}{*}{ ЖСЗДК } & 4,0 & 2,5 & 11,0 & 3,8 & 3,8 & 8,0 & 0,10 & \multirow{3}{*}{$\leq 0,4$} & \multirow{3}{*}{$\mathrm{OcH}$} \\
\hline & $\cdots$ & $\ldots$ & 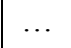 & $\ldots$ & $\ldots$ & $\ldots$ & $\ldots$ & & \\
\hline & 4,8 & 3,2 & 12,5 & 4,5 & 4,0 & 10,0 & 0,15 & & \\
\hline
\end{tabular}

Таблиця 3

Гранулометричний склад та питома поверхня дисперсних композицій

\begin{tabular}{|c|c|c|}
\hline Сполука & $\begin{array}{c}\text { Питома поверхня S, } \\
\mathrm{m}^{2} / \Gamma\end{array}$ & $\begin{array}{c}\text { Кількість } \\
\text { частинок в } 1 \text { г }\end{array}$ \\
\hline \hline $\mathrm{TiC}$ & $2,44 \ldots 12,19$ & $3,1 \cdot 10^{12}$ \\
\hline $\mathrm{TiN}$ & $2,21 \ldots 11,0$ & $2,9 \cdot 10^{12}$ \\
\hline $\mathrm{Ti}(\mathrm{CN})$ & $2,42 \ldots 12,02$ & $3,1 \cdot 10^{12}$ \\
\hline
\end{tabular}

За структурною та хімічною відповідністю як найефективніший модифікатор жароміцних нікелевих сплавів запропонований комплексний модифікатор на основі нанодисперсного карбонітриду титану, отриманий плазмохімічним синтезом. Наночастки карбонітриду титану розміром 50...100 нм [9] є найдрібнішими центрами кристалізації в розплаві нікелевого сплаву, що сприяють об'ємній кристалізації виливка.

Для визначення впливу наномодифікування досліджували структуру сплаву у вихідному і модифікованому станах. Структура зразків немодифікованого сплаву ЖСЗ вкрай неоднорідна по перетину. На поверхні зразка виявляються великі дендрити з грубими лініями ковзання (рис. 1, а); утворюються великі витягнуті зерна, орієнтовані перпендикулярно до поверхневого шару.

У модифікованих зразках зерна мали поліедри- чну форму і практично однаковий розмір по перетину шліфа. На рис. 1, а зображена макроструктура нікелевого сплаву ЖСЗ у вихідному стані. У мікроструктурі виявили зерна $\gamma$-фази неправильної форми з безліччю великих включень, що негативно впливає на характеристики міцності сплаву.

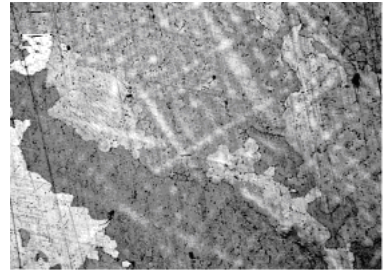

a

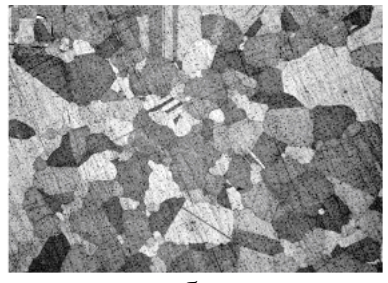

6
Рис. 1. Макроструктура немодифікованого (а) та модифікованого (б) нікелевого сплаву

Виявлено великі включення на стику меж зерен, що можуть бути концентраторами напружень і осередками розвитку тріщин під час експлуатації. Вони мали різну форму: багатогранники і пластини довжиною $6 . .14$ мкм; включення квадратної форми - зі стороною 4...6 мкм.

Під час вивчення мікроструктури модифікованого сплаву встановили, що всі присутні в сплаві включення (карбіди, інтерметаліди, карбонітриди) рівномірно розподілені по всьому об'єму зразка і не утворюють скупчень і груп. Карбіди і карбонітриди формувалися в основному у середині зерен. Всі включення мали практично однаковий розмір $1 \ldots 5$ мкм. Таким чином, в результаті модифікування досягнуто подрібнення структурних складників сплаву в 3-4 рази та загальна стабілізація структури.

Модифікування призводить до істотної зміни структури сплаву ЖСЗ порівняно з немодифікованим станом. Структура модифікованого однорідна, дрібнозерниста. У центрі шліфа зустрічаються двійникові утворення, які свідчать про високу чистоту твердого розчину.

Грубозерниста і малопластична матриця нікелевого сплаву перебуває під дією великого локального навантаження, що сприяє передчасному розтріскуванню межами зерен. Тому основне завдання модифікування - одержати однорідну дрібнозернисту структуру сплаву. Досягнуто подрібнення зерна нікелевого сплаву ЖС3 в 3-5 разів після модифікування нанокомпозиціями. Перевага дрібніших зерен у литих нікелевих сплавах пов'язана зі здатністю матеріалу розподіляти напруги серед більшої кількості меж, що призводить до зниженої деформації на межі зерен.

Результати досліджень зламів ударних зразків сплаву ЖС3 у початковому стані і після модифікування наведено на рис. 2. На рис. 2, а чітко видно крихкий злам, на рис. 2, б - в'язкий ямковий. Вна- 
слідок руйнування модифікованого зразка за механізмом в'язкого руйнування різко, на $40 \ldots 44 \%$, збільшився показник ударної в'язкості зразків $\left(\mathrm{KCU}=490\right.$ кДж $\left./ \mathrm{m}^{2}\right)$ порівняно 3 вихідними

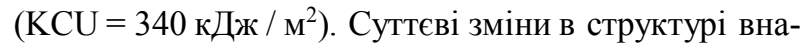
слідок модифікування свідчать про істотну зміну характеристик міцності, пластичності і експлуатаційних властивостей сплаву. Фізико-механічні та експлуатаційні характеристики немодифікованого сплаву ЖС3 вивчали на зразках, отриманих за серійною технологією, а модифікованого - на зразках, одержаних зі застосуванням модифікувального комплексу розробленого складу в кількості 0,1...0,2\% мас. від маси розплаву. Зразки піддавали термічній обробці за стандартним режимом: нагрівання до $1210 \pm 10^{\circ} \mathrm{C}$, витримка 4:00, охолодження у повітрі. В результаті модифікування мікротвердість матриці сплаву підвищилася на $17 . .24$ \% (рис. 3).

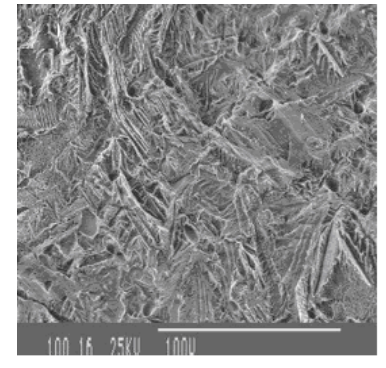

a

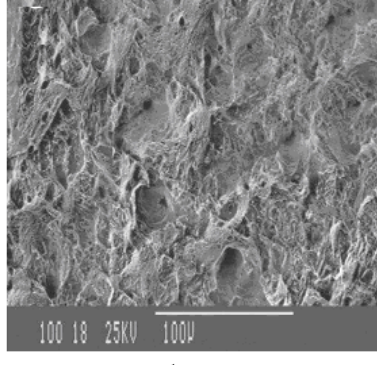

6
Рис. 2. Фрактографія зламів немодифікованого (а) і модифікованого (б) нікелевого сплаву

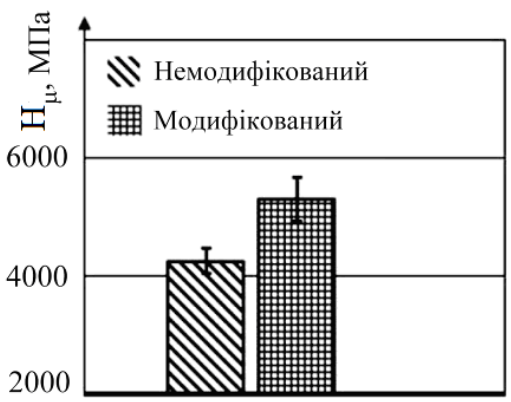

Рис. 3. Мікротвердість матриці сплаву ЖСЗДК до і після модифікування

Однорідний розподіл легувальних елементів в об'ємі сплаву ЖС3 призводить до збільшення мікротвердості, посилення легування сплаву і додаткового зміцнення матриці дисперсними частками. Значне підвищення мікротвердості матриці сплаву свідчить і про додаткове насичення $\gamma$-твердого розчину титаном 3 нанодисперсного модифікатора. Зі зростанням вмісту титану в сплаві збільшувалась кількість зміцнювальної $\gamma^{\prime}$-фази внаслідок переходу титану в твердий розчин і додаткової його участі в утворенні вторинної $\gamma^{\prime}$-фази під час розпаду твердого розчину за охолодження.
Кращі механічні властивості мали зразки, отримані з модифікуванням. Межа міцності сплаву ЖСЗДК $\sigma_{\mathrm{B}}$ збільшилася в середньому до 1152 МПа або на $8 \ldots 10 \%$; межа плинності $\sigma_{0,2}$ - до 825 МПа або на $10 \ldots 13 \%$; відносне видовження $\delta$ - до $20,6 \%$ або на $19 . .21 \%$; ударна в'язкість KCU різко збільшилася до 490 кДж/м² або на $40 \ldots 44$ \%. Результати механічних випробувань підтверджують ефективність і доцільність модифікування жароміцних нікелевих сплавів.

Висока жаротривкість - одна 3 важливих вимог, що висувають до сплавів для лопаток авіаційних двигунів. Межі витривалості лопаток з корозійними пошкодженнями можуть знижуватися в кілька разів, і це зниження посилюється зі збільшенням часу випробувань. На неї суттєво впливає і глибина корозійного пошкодження.

Жаротривкість визначали в промислових умовах при $1000 \pm 5^{\circ} \mathrm{C}$ впродовж заданої тривалості від 2,5 до 15 год. Випробовували гравіметричним методом, за зміною маси зразків і металографічним методом заміру глибини корозії.

Мікроаналізом поперечних шліфів встановили, що у всіх зразках присутнє внутрішне виразкове окиснення. Інтенсивніше високотемпературне окиснення спостерігали в немодифікованих зразках глибиною 40 мкм. Після 15 год випробовувань на поверхні модифікованих зразків виявили локальні корозійні пошкодження з утворенням оксидів, що залягають на глибину не більше 30 мкм. Таким чином, корозійно-тривкішими виявилися модифіковані зразки. Після випробувань на жаротривкість при $1000^{\circ} \mathrm{C}$ глибину корозії в модифікованому сплаві вдалося зменшити в середньому на 10 мкм, тобто на 25 \% порівняно $з$ немодифікованим станом.

\section{Висновки}

1. Проаналізований вплив легувальних елементів жароміцних нікелевих сплавів на структуру, зміцнення та корозійну тривкість.

2. Для обробки нікелевих розплавів запропоновано комплексний модифікатор на основі карбонітриду титану з розміром частинок 50..100 нм, отриманий способом плазмохімічного синтезу. Визначено гранулометричний склад порошків на основі титану та їх питома поверхня: від 2,4 до 12,2 м²/г.

3. Дослідженням макро- і мікроструктури нікелевих сплавів у ЖСЗ встановлено зменшення зерна модифікованого сплаву в $3 \ldots .5$ разів та подрібнення структурних складових.

4. Механічні випробування зразків показали підвищення усіх параметрів у модифікованому стані: $\sigma_{B}$ на $10 \% ; \sigma_{0,2}$ - на $13 \% ; \delta$ - на $20 \%$ та KCU на $40 \%$ в порівнянні з вихідними зразками. Випробування зразків на жаротривкість показали зменшення глибини 
корозії при температурі $1000^{\circ} \mathrm{C}$ в модифікованому стані в середньому на $25 \%$, що підвищує ефективність обробки сплавів нанодисперсними матеріалами.

\section{Література}

1. Калинина, Н. Е. Микролегирование скандием как способ повышения прочности алюминиевых сплавов [Текст] / Н. Е Калинина, О. А. Каваи // Вестник днепровского ун-та, 2004. - № 12. - С. 26-29.

2. Елагин, В. И. Легирование деформируемых алюминиевых сплавов переходными металлами [Текст] / В. И. Елагин. - М. : Металлургия, 1975. $-248 c$.

3. Мальцев, М. В. Металлография промышленных иветных металлов и сплавов [Текст] / М.В. Мальчев.-М. : Металлургия, 1970. - 368 с.

4. Большаков, В. І. Наноматеріали і нанотехнологї [Текст] / В. І. Большаков, В. 3. Куцчова, T. В. Котова. - Дніпро : ПДАБА, 2016. - 220 с.

5. Калинина, Н. Е. Получение высокопрочных алюминиевых сплавов модифицированием ультрадисперсными композициями [Текст] / Н. Е. Калинина, О. А. Кавац // Авиаџионно-космическая техника и технология. - 2005. - № 8(24). - C. 18-20.

6. Получение нанодисперсных модификаторов для обработки жаростойких сплавов [Текст] / Н. Е. Калинина, О. А. Кавац, В. Т. Калинин, В. П. Белояриева // Авиационно-космическая техника и технология. - 2007. - № 8 (44). - C. 41-43.

7. Young-Dong, K. The effect of grain refining and oxide inclusion on the fluidity of $\mathrm{Al}-4,5 \mathrm{Cu}-0,6 \mathrm{Mn}$ and A356 alloys [Text] / K. Young-Dong, L. Zin-Hyoung // Mater. Sci. and Eng. - 2003. - № 1-2. - P. 372-376.

8. Каблов, Е. Н. Литье лопатки газотурбинных двигателей (сплавы, технология, покрытия) [Текст] / Е. Н. Каблов. - М. : МИСИС, 2001. - 632 c.

9. Мальцев, П. П. Наноматериаль. Нанотехнологии. Наносистемная техника: мировые достижения за 2005 год [Текст] / П. П. Мальиев. - М. : Техносфера, 2006. - 152 c.

10. Пат. Украӥни на корисну модель № 82163, МПК С22C 19/03. Комплексний наномодифікатор нікелевих сплавів [Текст] / Калініна Н. С., Калиновська А. С., Калінін В. Т., Вілішук 3. В., Носова Т. В. ; власник Дніпропетровський начіональний університет імені Олеся Гончара. - № и 201300612 ; заявл. 17/01/2-13 ; опубл. 25.07.2013, Бюл. № 14. - 5 c.

\section{References}

1. Kalynyna, N. E., Kavats, O. A. Mykrolehyrovanye skandyem kak sposob povyshenyya prochnosty alyumynyevykh splavov [Microalloying with scandium as a way to increase the strength of aluminum alloys]. Vestnyk dneprovskoho un-ta, 2004, no. 12, pp. 26-29 [in Russian].

2. Elahyn, V. Y. Lehyrovanye deformyruemykh alyumynyevykh splavov perekhodnymy metallamy [Alloying of deformable aluminum alloys with transition metals]. Moscow, Metallurhyya Publ., 1975. 248 p. [in Russian].

3. Mal'tsev, M. V. Metallohrafyya promyshlennykh tsvetnykh metallov $y$ splavov [Metallography of industrial non-ferrous metals and alloys]. Moscow: Metallurhyya Publ., 1970. 368 p. [in Russian].

4. Bol'shakov, V. I., Kutsova, V. Z., Kotova, T. V. Nanomaterialy $i$ nanotekhnolohiyi [Nanomaterials and nanotechnologies]. Dnipro, PDABA Publ., 2016. 220 p. [in Russian].

5. Kalynyna, N. E., Kavats, O. A. Poluchenye vysokoprochnykh alyumynyevykh splavov modyfytsyrovanyem ul'tradyspersnymy kompozytsyyamy [Obtained high-strength aluminum alloys by modifying with ultradispersed compositions]. Aviacijno-kosmicna tehnika $i$ tehnologia - Aerospace technic and technology, 2005, no. 8(24), pp. 18-20. [in Russian].

6. Kalynyna, N. E., Kavats, O. A., Kalynyn, V. T., Beloyartseva, V. P. Poluchenye nanodyspersnykh modyfykatorov dlya obrabotky zharostoykykh splavov [Obtaining nanodispersed modifiers for processing heatresistant alloys]. Aviacijno-kosmicna tehnika $i$ tehnologia - Aerospace technic and technology, 2007, no. 8 (44), pp. 41-43. [in Russian].

7. Young-Dong, K., Zin-Hyoung L. The effect of grain refining and ox-ide inclusion on the fluidity of Al4,5Cu-0,6Mn and A356 alloys. Mater. Sci. and Eng., 2003, no. 1-2, pp. 372-376. [in English].

8. Kablov, E. N. Lytye lopatky hazoturbynnykh dvyhateley (splavy, tekhnolohyya, pokrytyya) [Cast blades of gas turbine engines ( alloys, technologies, coatings]. Moscow, MYSYS Publ., 2001. 632 p. [in Russian].

9. Mal'tsev, P. P. Nanomateryaly. Nanotekhnolohyy. Nanosystemnaya tekhnyka: myrovye dostyzhenyya za 2005 hod [Nanomaterials. Nanotechnologies. Nanosystem engineering: world achievements for 2005]. Moscow, Tekhnosfera Publ., 2006. 152 p. [in Russian].

10. Kalinina, N. Ye., Kalynovska, A. Ye., Kalinin, V. T., Vilischuk, Z. V., Nosova, T. V. Kompleksnyy nanomodyfikator nikelevykh splaviv [Complex nanomodifier of nickel alloys]. Patent Ukraine, no. 82163, 2013. [in Ukrainian].

Поступила в редакиію 11.04.2018, розглянута на редколегії 27.07.2018

\section{ПОВЫШЕНИЕ СТРУКТУРНОЙ СТАБИЛЬНОСТИ И СВОЙСТВ ЖАРОПРОЧНЫХ НИКЕЛЕВЫХ СПЛАВОВ ДЛЯ ЛОПАТОК ГТД ОБРАБОТКОЙ НАНОМАТЕРИАЛАМИ}

М. В. Грекова, Н. Е. Калинина, В. Т. Калинин, М. В. Гученков, Е. А. Дюжур, А. С. Дудников

Проведен аналитический обзор существующих представлений по проблеме повышения жаропрочности, жаростойкости и долговечности жаропрочных никелевых сплавов группы ЖС лопаток газотурбинных двигателей. Проведен анализ влияния легирующих элементов сплавов на структурные превращения, виды упрочнения и коррозионную стойкость. Для обработки никелевых расплавов предложен комплексный по- 
рошковый модификатор на основе карбонитрида титана $\mathrm{Ti}(\mathrm{CN})$ с размером частиц $50 \ldots 100$ нм. Определены параметры наномодификатора. Исследована макро- и микроструктура никелевых сплавов ЖС 3 , ЖСЗДК. В модифицированных образцах достигнуто измельчение зерна в $3 \ldots 5$ раз и стабилизация структуры по сравнению с исходным состоянием. Достигнуто также повышение механических свойств сплавов: $\sigma_{\mathrm{B}}$ на $10 \%$; $\sigma_{0,2}-$ на $13 \%$; $\delta$ - на $20 \%$ и KCU на $40 \%$. Испытания на высокотемпературную коррозию показали уменьшение глубины коррозии модифицированных образцов на 25 \%, что подтверждает эффект модифицирования сплавов нанодисперсными модификаторами.

Ключевые слова: жаропрочные никелевые сплавы, наномодификатор, структура, свойства, лопатки газотурбинных двигателей.

\section{INCREASE OF STRUCTURAL STABILITY AND PROPERTIES OF HEAT-RESISTANT NICKEL ALLOYS FOR GTE SHOOTERS BY NANOMATERIAL TREATMENT \\ M. V. Grekova, N. E. Kalinina, T. V. Kalinin, M. V. Guchenkov, Y. O. Djur, A. S. Dudnikov}

An analytical review of existing views on the problem of increasing the heat resistance, heat resistance, and durability of high-temperature nickel alloys of the $\mathrm{ZhC} 3$ group of blades of gas turbine engines is carried out. The effect of alloying elements of alloys on structural transformations, types of hardening and corrosion resistance is analyzed. A complex powder modifier based on titanium carbonitride $\mathrm{Ti}(\mathrm{CN})$ is proposed for processing nickel melts.

The choice of nanodispersed $\mathrm{Ti}(\mathrm{CN})$ carbonitride powders of a fraction of less than $100 \mathrm{~nm}$ as modifiers of lowalloy steels is substantiated. It has been established that $\mathrm{Ti}(\mathrm{CN})$ titanium carbonitride particles have a face-centered crystal lattice. The necessary criteria for the selection of nanopowder modifiers have been obtained: insolubility in the melt, correspondence of crystal lattices with the matrix of steel, proportionality with the critical radius of the austenite embryo during crystallization. A mechanism for the interaction of a steel melt with a layer of a nanodisperse composition is established. The macro- and microstructure of nickel alloys $\mathrm{ZhC3}$, ZhC3DK was investigated.

An analysis of microdiffraction patterns of particles is carried out, the nanopowders are shown to belong to solid crystalline bodies with a metallic bond. The coarse-grained and low-plastic matrix of the nickel alloy is under the influence of a large local loading, which contributes to the premature cracking of grain boundaries. Modification leads to significant changes in the structure of the alloy $\mathrm{ZhC3}$ in comparison with the unmodified state.

The structure of ZhC3 after modification is homogeneous, fine-grained. In modified samples, the grinding of grain was achieved $3 \ldots 5$ times and the structure was stabilized in comparison with the initial state. Mechanical studies of samples in a modified state showed an increase in all parameters: tensile strength by $10 \%$; yield strength by $13 \%$; the elongation by $20 \%$ and the impact strength by $40 \%$ compared to the original samples. Tests of samples for heat resistance showed a decrease in the depth of corrosion at a temperature of $1000{ }^{\circ} \mathrm{C}$ in the modified state on average by $25 \%$, which confirms the effect of modifying the alloys with nanodispersed modifiers.

Keywords: heat-resistant nickel alloys, nanomodifiers, structure, properties, gas turbine blades.

Грекова Марина Викторовна - инженер отдела перспективных технологий ГП «КБ «Южное», Днепр, Украина, e-mail: marina.grekova.kbu@gmail.com.

Калинина Наталия Евграфовна - д-р техн. наук, профессор кафедры технологии производства, Днепропетровский национальный университет им. О. Гончара «ДНУ», Днепр, Украина, е-таil: kalinina.dnu@gmail.com.

Калинин Василий Тимофеевич - д-р техн. наук, профессор кафедры литейного производства, Национальной металлургической академии Украины «НМетАУ», Днепр, Украина, e-mail: kalinina.dnu@gmail.com.

Гученков Михаил Васильевич - инженер-конструктор 1 категории ГП «КБ «Южное», Днепр, Украина, e-mail: gtpmik@gmail.com.

Джур Евгений Алексеевич - д-р техн. наук, проф. кафедры технологии производства, Днепропетровский национальный университет им. О. Гончара «ДНУ», Днепр, Украина, e-mail: material.ftf@gmail.com.

Дудников Александр Сергеевич - аспирант, Запорожский национальный технический университет «ЗНТУ», Запорожье, Украина, zac.office@meta.ua.

Maryna Victorovna Grekova - Engineer-designer of the 3d category of SE "Yuzhnoye", Dnipro, Ukraine, e-mail: marina.grekova.kbu@gmail.com.

Natalia Evgrafovna Kalinina - Doctor of Technical Sciences, Prof. Department of Production Technology, Dnipropetrovsk National University. O. Gonchar "DNU", Dnipro, Ukraine, e-mail: kalinina.dnu@gmail.com.

Vasiliy Timofeyevich Kalinin - Doctor of Technical Sciences, Prof. Department of foundry production, National Metallurgical Academy of Ukraine "NMetAU", Dnieper, Ukraine, e-mail: kalinina.dnu@gmail.com.

Michael Vasil'yevich Guchenkov - Engineer-designer of the 1st category of SE "Yuzhnoye", Dnipro, Ukraine, e-mail: gtpmik@gmail.com.

Yevgeniy Alekseyevich Djur - Doctor of Technical Sciences, Prof. Department of Production Technology, Dnipropetrovsk National University. O. Gonchar "DNU", Dnipro, Ukraine, e-mail: material.ftf@gmail.com.

Aleksandr Sergeyevich Dudnikov - PhD student, Zaporizhia National Technical University, Zaporizhia, Ukraine, e-mail: zac.office@meta.ua. 